\title{
Primary B lymphoma tumor of the ulnar nerve. Case report
}

\author{
Laura Sita-Alb, Raluca Sobec, Lucian Fodor
}

Department of Plastic and Reconstructive Microsurgery, Emergency District Hospital, ClujNapoca, Romania

DOI: $10.15386 / \mathrm{mpr}-1315$

Manuscript received: 25.03 .2019

Received in revised form: 10.05.2019

Accepted: 26.05.2019

Address for correspondence:

laura.sita.alb@gmail.com

\begin{abstract}
Primary lymphoma of a peripheral nerve is a very rare condition with only a few cases reported in the medical literature. Primary lymphoma of a peripheral nerve in the upper extremity was reported in only four cases in the English and French literature. We present a case of a 54-year-old man, in good health, without other medical conditions, who came to our unit complaining of paraesthesia in the ulnar territory of the hand. MRI investigation showed a mass situated in the ulnar nerve sheaths, in the lower third of the arm. Surgical exploration and excision were performed. Morphopathological results revealed a very uncommon tumor, a large B cell diffuse non-Hodgkin lymphoma, the second primary ulnar nerve lymphoma presented in the literature.

Early diagnosis and a better understanding of the pathogenesis of these tumors may change medical and surgical strategies, with further enhancement of survival rates.
\end{abstract}

Keywords: peripheral nerve lymphoma, ulnar nerve lymphoma, ulnar nerve tumor, nerve tumor differential diagnose, nerve lymphoma treatment

\section{Introduction}

Lymphoma is a malignant tumor of the white blood cells. There are numerous types and subtypes of lymphomas. They are a malignant transformation of either B lymphocytes, $\mathrm{T}$ lymphocytes or their subtypes.

Neurological signs of peripheral nerve involvement are seen in the late stages of lymphomas in about $5 \%$ of patients [1], found for both $\mathrm{B}$ and $\mathrm{T}$ lymphoma, all non-Hodgkin lymphomas. The neurological signs in lymphoma can be caused by multiple mechanisms, subsequent to different drugs used for treatment (especially vinca alkaloids), to radiotherapy, as a paraneoplastic syndrome [1] consequent to compression, or to a direct invasion of the peripheral nerves [2]. They can be found as a recurrence of the lymphoma after treatment, or associated with a central nervous system lymphoma [3]. Usually multiple nerves are affected by this condition, and single nerve involvement is very rare.

Peripheral nervous symptoms lead patients to seek medical consultations. When a lymphoma is identified, further investigations usually reveal advanced stage of the disease. Lymphocytes infiltrating the nerve (nerve roots, trunks, plexuses, and cranial nerves) is called neurolymphoma. When the nerve is the first site involved in this malignancy, the disorder is considered as primary neurolymphoma. When only the peripheral nerves are involved, the condition is called primary lymphoma of the peripheral nerves [4]. Primary lymphoma of the peripheral nervous system is a very rare entity and represents a malignant tumor, with no other biological or imaging signs of generalized lymphoma [5].

\section{Case report}

Our patient is a 54 year old man with no medical history, in good health, with no other complaints except for paraesthesia in the ulnar territory of the hand. Ultrasound revealed a tumor in the medial aspect of the arm, and the patient was referred to MRI, which showed a collection with a hematic aspect situated within the ulnar nerve sheaths, $10 \times 1.5 \mathrm{~cm}$, in the distal third of the arm (Figure 1). Lateral to this collection, another tumor was seen in the subcutaneous tissue, welldelimitated, $4.2 \times 2.5 \mathrm{~cm}$. Oedema of arm and forearm soft tissue was also seen. The interpretation was that of a possible hematoma for both lesions. 


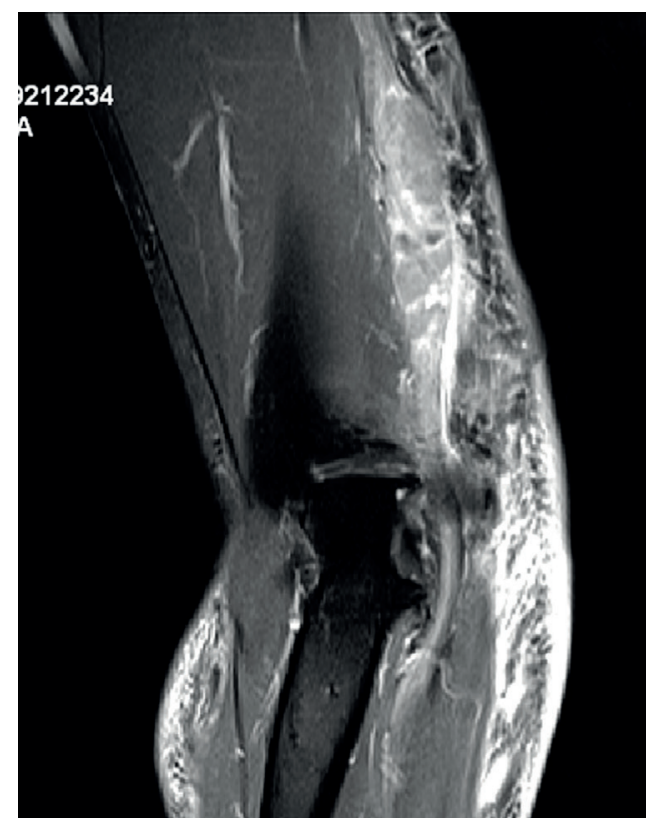

Figure 1. MRI showing ulnar nerve tumor.

Surgical exploration and excision were performed. The tumor infiltrated the nerve sheaths and was seen also between the nerve fascicles (Figure 2). Complete excision was tried, without sectioning the nerve fascicles (Figure 3). The mass lateral to the ulnar nerve was also excised.

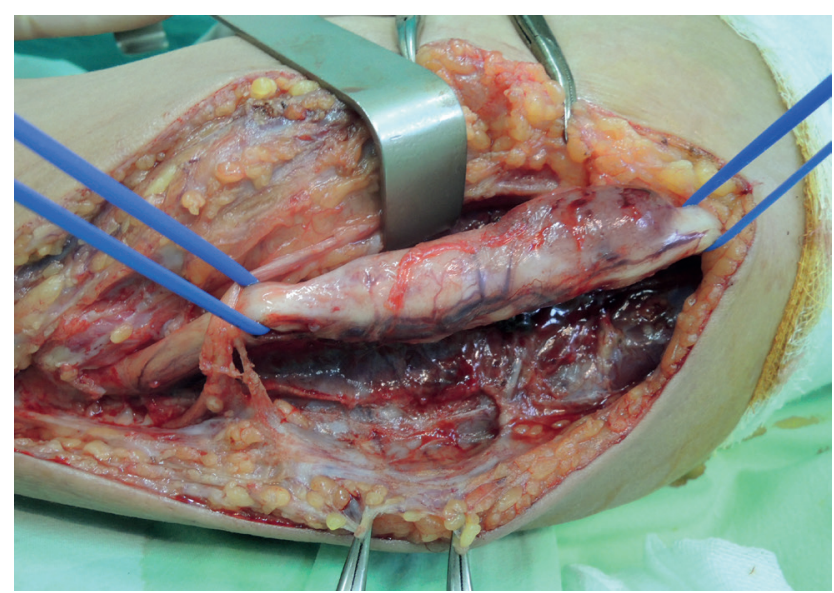

Figure 2. Intraoperative findings. Ulnar nerve tumor infiltrating the nerve sheaths.

Histopathological and immunohistochemistry results found an extranodal diffuse large B cell lymphoma (Figure 4). The immunohistochemistry profile was: CD20 positive (Figure 5), bcl2-pozitive, MUM1-positive, LCApositive, Vimentin-positive, CK (AE1AE3)-negative, S100negative, CD3-negative, bcl6-negative $\mathrm{CD}$ 10- negative, CD5-negative. A proliferative index of approximately $70 \%$ was appreciated using the Ki 67 immune-marking.

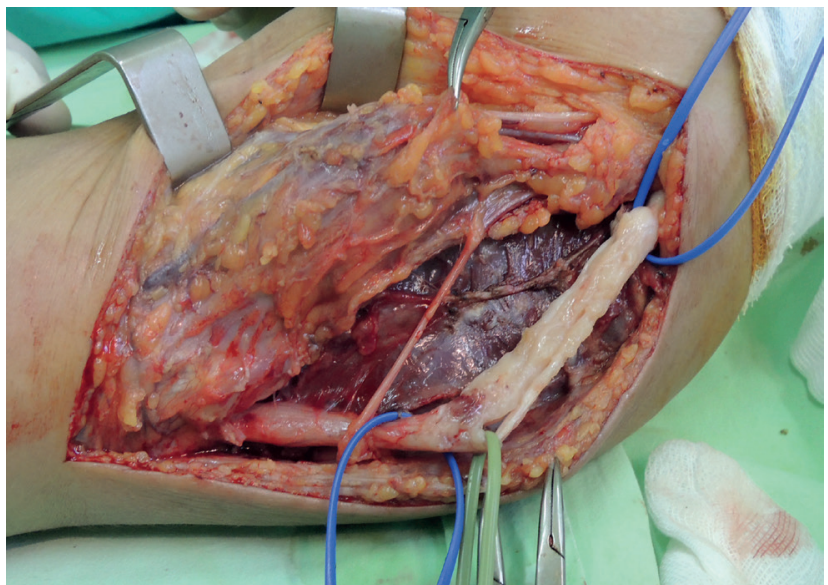
attempted.

Figure 3. Tumor intra-neural excision. Complete excision

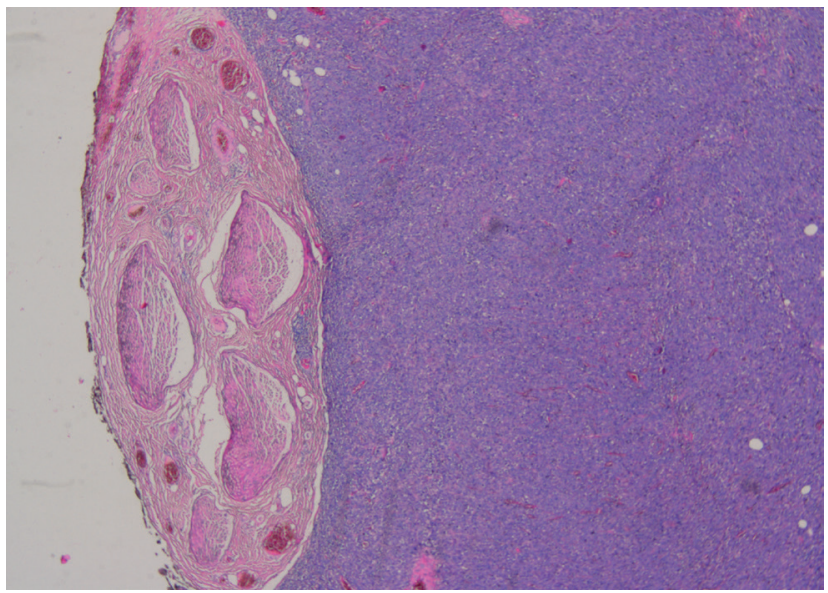

Figure 4. Hematoxylin-eosin (4). Nervous fascicles (in the left of the image) and a lymphoid proliferation with diffuse growing.

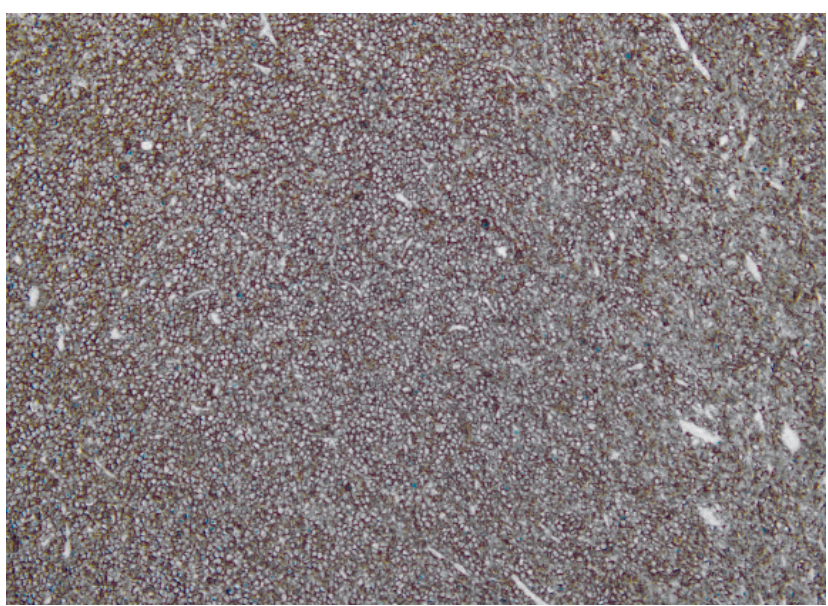

Figure 5. Imunohistochemical staining for CD20 (10. The neoplastic lymphocytes show positive reaction for CD20. 
In the second tumor, which was lateral to the ulnar nerve, mostly necrotic tissue was found, with a few marginal lymphoid cells found in the tissue adjacent to the necrotic mass. Two weeks after the operation, the patient developed a seroma at the surgical site and approximately $65 \mathrm{ml}$ of serous liquid was evacuated.

Cervical, thoracic and abdominal CTs showed right axillary satellite adenopathy of $4.5 \times 3.4 \mathrm{~cm}$, with no other evidence of generalized lymphoma. Bone marrow biopsy was also negative.

The patient was referred to the hematology department, and chemotherapy treatment was initiated. R CHOP protocol was initiated for our patient, a combination of monoclonal antibody: rituximab, with chemotherapy: cyclophosphamide, doxorubicin, vincristine and a steroid: prednisolone.

\section{Discussion}

Primary lymphoma of the peripheral nervous system is a rare entity with few cases reported in the literature, only four of which involved the nerves of the upper limb, two affecting the radial nerve [2,6], one the median nerve [7] and one the ulnar nerve [8] (Table I). Sciatic nerve lymphoma was found in more than half of the reported cases (10 sciatic nerve lymphomas from a total of 17 primary lymphomas of the peripheral nerves).

All the patients sought medical treatment for sensitive and motor symptoms that developed in the area of the affected nerve. Although there are only 17 reported cases in the English and French literature, the patients' mean age is 58 years (34-72 years), and affecting both males and females in approximately the same ratio $(9$ males, 8 females).

Prior to surgery, patients usually underwent electromyographic studies followed by an MRI or CT scan. In one case the CT did not find any modifications, and the MRI taken afterwards found enlargement of the sciatic nerve [9]. The images found on MRI and CT scans were nonspecific, ambiguous, showing enlargement of the nerve, oedema, diffuse swelling, or a mass surrounding the nerve. Surgical exploration and excisions or just a biopsy were done. In most of the reported cases the tumor involved the epineurium and even extended to the surrounding tissue. In the 17 cases reported, six died in the follow-up period (650 months), and the mean follow-up in these studies was approximately three years.

Table I. Summary of reported cases of primary lymphoma of the peripheral nerve.

\begin{tabular}{|c|c|c|c|c|c|c|c|c|c|c|c|c|}
\hline & $\begin{array}{l}\text { Affected } \\
\text { nerve }\end{array}$ & $\begin{array}{l}\text { Type } \\
\text { of } \\
\text { NHL }\end{array}$ & $\begin{array}{l}\text { Extraneural } \\
\text { extension }\end{array}$ & CD19 & CD20 & CD56 & CD45 & $\begin{array}{l}\text { CDKN2A/ } \\
\text { P16 gene } \\
\text { deletion }\end{array}$ & Associated diseases & Treatment & Survival+ & $\begin{array}{l}\text { Gender } \\
\text { / Age }\end{array}$ \\
\hline 1.Our case & Ulnar & B & yes & & * & & & & $\begin{array}{l}\text { no+concomittant } \\
\text { axillary lymph nodes }\end{array}$ & Excision $+\mathrm{ChT}$ & $\begin{array}{l}\text { alive at } 12 \\
\text { months }\end{array}$ & $\mathrm{M} / 50$ \\
\hline 2.Teisser 1992 [12] & Ulnar & B & yes & & & & & & DM & $\begin{array}{l}\text { Excisional } \\
\text { biopsy+ChT }\end{array}$ & $\begin{array}{l}\text { alive at } 31 \\
\text { months }\end{array}$ & $\mathrm{M} / 68$ \\
\hline 3.Kim et al 1998 [13] & Median & $\mathrm{T}$ & yes & & $*$ & $*$ & $*$ & & not mentioned & $\begin{array}{l}\text { Excisional } \\
\text { biopsy+RT }\end{array}$ & $\begin{array}{l}\text { alive at } 24 \\
\text { months }\end{array}$ & $\mathrm{F} / 70$ \\
\hline 4.Gonzalvo et al 2010 [14] & Radial & B & yes & & & & & $*$ & $\begin{array}{l}\text { irritable bowel disease, } \\
\text { asthma, Graves }\end{array}$ & $\begin{array}{l}\text { Partial excision } \\
\text { +partial ChT }\end{array}$ & $\begin{array}{l}\text { alive at } 65 \\
\text { months }\end{array}$ & $\mathrm{F} / 69$ \\
\hline 5.Misdraji et al 2000 [2] & Radial & B & yes & & * & & $*$ & * & $\begin{array}{l}\text { no+concommittant } \\
\text { axillary lymph nodes }\end{array}$ & $\begin{array}{l}\text { Biopsy+ChT } \\
+ \text { RT }\end{array}$ & $\begin{array}{l}\text { dead at } 43 \\
\text { months }\end{array}$ & $\mathrm{F} / 63$ \\
\hline 6. & T2 Spinal & & no & & * & & * & & no & $\begin{array}{l}\text { Excision }+ \text { ChT } \\
+\mathrm{RT}\end{array}$ & $\begin{array}{l}\text { alive at } 54 \\
\text { months }\end{array}$ & $\mathrm{M} / 48$ \\
\hline 7. & Sciatic & B & no & & $*$ & & $*$ & & no & $\begin{array}{l}\text { Partial excision } \\
+\mathrm{ChT}+\mathrm{RT}\end{array}$ & $\begin{array}{l}\text { alive at } 57 \\
\text { months }\end{array}$ & $\mathrm{F} / 62$ \\
\hline 8. & Sciatic & B & no & & * & & * & $*$ & no & $\begin{array}{l}\text { Partial excision } \\
+\mathrm{ChT}\end{array}$ & $\begin{array}{l}\text { dead at } 6 \\
\text { months }\end{array}$ & $\mathrm{M} / 49$ \\
\hline 9.Purohit et al 1986 [15] & Sciatic & B & no & & & & & & $\begin{array}{l}\text { rheumatoid factor+ } \\
\text { antinuclear factor }+\end{array}$ & Excision $+\mathrm{RT}$ & $\begin{array}{l}\text { alive at } 36 \\
\text { months }\end{array}$ & $\mathrm{F} / 64$ \\
\hline 10.Pillary et al 1988 [6] & Sciatic & B & yes & & & & & & no & Biopsy+RT & $\begin{array}{l}\text { alive at } 12 \\
\text { months }\end{array}$ & $\mathrm{M} / 61$ \\
\hline 11.Eusebi et al 1990 [8] & Sciatic & $\mathrm{B}$ & no & & & & & & not mentioned & $\begin{array}{l}\text { Excision+RT } \\
+ \text { Cht }\end{array}$ & $\begin{array}{l}\text { dead at } 16 \\
\text { months }\end{array}$ & $\mathrm{M} / 72$ \\
\hline 12.Kanamori et al 1995 [16] & Sciatic & $\mathrm{T}$ & $\begin{array}{l}\text { data } \\
\text { unavailable }\end{array}$ & & & & & & data unavailable & $\begin{array}{l}\text { Biopsy+Cht } \\
+ \text { RT }\end{array}$ & $\begin{array}{l}\text { alive at } 30 \\
\text { months }\end{array}$ & $\mathrm{M} / 34$ \\
\hline 13.Roncaroli 1997 [17] & Sciatic & B & $\begin{array}{l}\text { data } \\
\text { unavailable }\end{array}$ & & & & & & data unavailable & $\begin{array}{l}\text { Biopsy+RT } \\
+ \text { Cht }\end{array}$ & $\begin{array}{l}\text { dead at } 50 \\
\text { months }\end{array}$ & $\mathrm{M} / 44$ \\
\hline 14.Rota et al 2006 [18] & Sciatic & $\mathrm{B}$ & $\begin{array}{l}\text { not } \\
\text { mentioned }\end{array}$ & & & & & & no & Biopsy+ChT & $\begin{array}{l}\text { alive at } 13 \\
\text { months }\end{array}$ & $\mathrm{F} / 44$ \\
\hline 15.Hinojosa et al 2000 [7] & Sciatic & B & $\begin{array}{l}\text { not } \\
\text { mentioned }\end{array}$ & & * & & & & no & $\begin{array}{l}\text { Nerve sheaths } \\
\text { excision }+ \text { ChT }\end{array}$ & $\begin{array}{l}\text { died at } \\
\text { approx } 4 \\
\text { months }\end{array}$ & $\mathrm{M} / 52$ \\
\hline 16.Descamps et al 2006 [19] & Sciatic & $\mathrm{B}$ & yes & & $*$ & & & & malignant melanoma & Biopsy+ChT & $\begin{array}{l}\text { alive at } 54 \\
\text { months }\end{array}$ & $\mathrm{M} / 55$ \\
\hline 17.Del Grande et al 2014 [5] & Multiple & B & yes & & $*$ & & & & no & $\begin{array}{l}\text { Biopsy+Cht } \\
+ \text { RT }\end{array}$ & $\begin{array}{l}\text { dead at } 19 \\
\text { months }\end{array}$ & $\mathrm{F} / 61$ \\
\hline 18.Sideras et al 2016 [20] & Peroneal & B & yes & $*$ & * & & & & HIV, Hep B & $\begin{array}{l}\text { Biopsy+Cht } \\
+ \text { RT }\end{array}$ & $\begin{array}{l}\text { not } \\
\text { mentioned }\end{array}$ & $\mathrm{F} / 65$ \\
\hline
\end{tabular}

Notes: $\mathrm{Cht}=$ chemotherapy; $\mathrm{RT}=$ radiotherapy; $\mathrm{DM}=$ diabetus mellitus 
The common characteristic of these primary peripheral nerve lymphomas is the absence of other clinical, paraclinical and imaging signs of generaliszd or central nervous system lymphoma. In the evolution of these tumors, involvement of the central nervous system (CNS) was frequently found [10].

Post mortem examination was undertaken in some of the reported cases $[2,10,11]$, but did not find lymphomas outside the peripheral and CNS $[2,10]$. A retroperitoneal tumor tissue was found together with a tumor in the arachnoidal space in the case reported by Eusebi et al [11].

Pathogenesis of the primary lymphoma of the peripheral nerve remains unsolved. Hematogenous spreading can be an explanation but, at the time of primary tumor diagnosis, no other sites of lymphoma involvement were found. The blood-nerve barrier offers protection from possible blood harmful factors [12]. This barrier can also explain the low response to chemotherapy for these tumors.

Another possible explanation for extranodal lymphomas can be found in MALT tumors (mucosa associated lymphoid tissue). These lymphomas have their starting point in the extranodal lymphoid tissue that can be found in the stomach and salivary and thyroid glands [2]. The existence of circulating immunoglobulins through the nerves is also known. Some polyneuropathies are due to these immunoglobulins (that can produce B cells) and react against the nerve. The presence of these cells in the nerve can explain the predisposition of nerve extensive infiltrations found in post mortem studies [2]. Moreover, it is believed that, in some primary lymphomas of the peripheral nerves, these tumors represent the initial site, and the later involvement of the CNS represents a secondary spreading site. In favor of this explanation is the absence of CNS involvement at the moment of diagnosis. According to Quinones-Hinojosa, if this pathogenetic mechanism can be responsible for secondary spreading of the tumor, then the initial treatment should be more aggressive, from initial radiotherapy to extensive surgery, or even limb amputation.

In an attempt to explain the pathogenesis of this disease and also its aggressiveness, the deletion of CDKN2A/ p16 gene was noted in some of the cases tested. It is known that deletions or alteration of this tumor suppressor gene is involved in numerous malignancies, including lymphomas. The alteration of this gene was found in $9 / 10$ cases with primary lymphoma of the brain studied by Zhang et al [13]. In the reported cases of primary lymphomas of the peripheral nervous system, this gene was assessed in only two studies; from the five patients in these two studies, the two patients that had alteration of p16 died in follow-up period.

Treatment in some cases involved complete excision of the tumor, or partial excision, or just biopsies $[2,5,9,14$ 18] followed by different protocols of chemotherapy, associated or not with radiotherapy, or radiotherapy alone $[7,9,19]$ (Table I).
The prognosis of primary lymphomas of the peripheral nervous system is difficult to establish, due to the small number of cases reported in the literature. From the 17 patients reported in the literature, six died in the follow up, with a mean of 23 months (range, 6-50 months). More generally, patients who developed neurolymphoma with the lymphoma had a survival rate of 21 months. The overall survival for patients with non-Hodkin lymphoma is $60 \%$ at 5 years according to the 2017 report of the American Cancer Society [20]. The prognosis of neurolymphoma is poorer than that of systemic lymphoma.

Currently the treatment of neurolymphoma is unsatisfactory [3], and the lower penetration of chemotherapy into the nerve is probably due to the nerveblood barrier, which can explain the poorer rates of survival.

There are many possible pathways of tumor spreading and a theory of a primary tumor that developed in the nerve. There is probably not only one pathogenesis explanation for these primary lymphomas of the peripheral nervous system, and determining which one is responsible for each tumor might change treatment strategies, the aggressiveness of treatment and the final outcome.

The need for early diagnosis of these aggressive and difficult to treat tumors is mandatory in the attempt to prolong patient survival. Therefore, a patient with peripheral nervous system symptoms must always be further investigated. The nervous signs of primary lymphoma of the peripheral nerves are superimposed on those of compression neuropathies. We can exclude different inflammatory polyneuropathies with a thorough clinical examination that shows unilateral, asymmetrical symptoms that develop quite rapidly, and no associated comorbidities were found in most of the reported cases.

Documenting these rare cases must be done for further medical and surgical progression of peripheral nerve lymphoma treatment.

\section{References}

1. Hughes RA, Britton T, Richards M. Effects of lymphoma on the peripheral nervous system. J R Soc Med. 1994;87:526530.

2. Misdraji J, Ino Y, Louis DN, Rosenberg AE, Chiocca EA, Harris NL. Primary lymphoma of peripheral nerve: report of four cases. Am J Surg Pathol. 2000;24:1257-1265.

3. Dantas Azevedo R, Reis F, Torresan Delamain M, de Souza CA. Involvement of cranial nerves in a patient with secondary central nervous system lymphoma. Rev Bras Hematol Hemoter. 2016;38:158-160.

4. Patrij K, Reiser M, Wätzel L, Pels H, Kowoll A, Herrlinger $\mathrm{U}$, et al. Isolated central nervous system relapse of systemic lymphoma (SCNSL): clinical features and outcome of a retrospective analysis. Ger Med Sci. 9:Doc11.

5. Del Grande A, Sabatelli M, Luigetti M, Conte A, Granata G, Rufini V, et al. Primary multifocal lymphoma of peripheral nervous system: case report and review of the literature. Muscle Nerve. 2014;50:1016-1022. 
6. Gonzalvo A, McKenzie C, Harris M, Biggs M. Primary non-Hodgkin's lymphoma of the radial nerve: case report. Neurosurgery. 2010;67:E872-E873.

7. Kim J, Kim YS, Lee EJ, Kang CS, Shim SI. Primary CD56positive NK/T-cell lymphoma of median nerve: a case report. J Korean Med Sci. 1998;13:331-333.

8. Teissier J. Primary malignant lymphoma localized in the trunk of the ulnar nerve at the elbow. A case report. Ann Chir Main Memb Super. 1992;11:170-172.

9. Pillay PK, Hardy RW Jr, Wilbourn AJ, Tubbs RR, Lederman RJ. Solitary primary lymphoma of the sciatic nerve: case report. Neurosurgery. 1988;23:370-371.

10. Quiñones-Hinojosa A, Friedlander RM, Boyer PJ, Batchelor TT, Chiocca EA. Solitary sciatic nerve lymphoma as an initial manifestation of diffuse neurolymphomatosis. Case report and review of the literature. J Neurosurg. 2000;92:165-169.

11. Eusebi V, Bondi A, Cancellieri A, Canedi L, Frizzera G. Primary malignant lymphoma of sciatic nerve. Report of a case. Am J Sur J Pathol. 1990;14:881-885.

12. Peters A, Palay SL, Webster HD. The Fine Structure of the Nervous System: Neurons and Their Supporting Cells. New York, NY: Oxford University Press; 1991: pp 384-394.

13. Zhang SJ, Endo S, Ichikawa T, Washiyama K, Kumanishi T. Frequent deletion and 5, $\mathrm{CpG}$ island methylation of the p16 gene in primary malignant lymphoma of the brain. Cancer Res. 1998;58:1231-1237.
14. Kanamori M, Matsui H, Yudoh K. Solitary T-cell lymphoma of the sciatic nerve: case report. Neurosurgery. 1995;36:1203-1205.

15. Roncaroli F, Poppi M, Riccioni L, Frank F. Primary nonHodgkin's lymphoma of the sciatic nerve followed by localization in the central nervous system: case report and review of the literature. Neurosurgery. 1997;40:618-621.

16. Rota S, Zincone A, Piatti M, Stanzani L, Teruzzi A, Vaiani S, et al. Solitary sciatic nerve lymphoma. J Periph Nerv Syst 2006;11:204.

17. Descamps MJ, Barrett L, Groves M, Yung L, Birch R, Murray NM, et al. Primary sciatic nerve lymphoma: a case report and review of the literature. J Neurol Neurosurg Psychiatry. 2006;77:1087-1089.

18. Sideras PA, Matthews J, Sakib SM, Ofikwu F, Spektor V. Neurolymphomatosis of the peripheral nervous system: a case report and review of the literature. Clin Imaging. 2016;40:1253-1256.

19. Purohit DP, Dick DJ, Perry RH, Lyons PR, Schofield IS, Foster JB. Solitary extranodal lymphoma of sciatic nerve. J Neurol Sci. 1986;74:23-34.

20. American Cancer Society: Cancer Facts and Figures 2017. Atlanta, Ga: American Cancer Society, 2017. Available from: https://www.cancer.org/content/dam/cancer-org/research/ cancer-facts-and-statistics/annual-cancer-facts-and-figures/ 2017/cancer-facts-and-figures-2017.pdf 